\title{
Bone Morphogenetic Protein 4 Mediates Estrogen-Regulated Sensory Axon Plasticity in the Adult Female Reproductive Tract
}

\author{
Aritra Bhattacherjee, ${ }^{1,2,5}$ M. A. Karim Rumi, ${ }^{3,6}$ Hinrich Staecker, ${ }^{1,2,4}$ and Peter G. Smith ${ }^{1,2,5,6}$ \\ ${ }^{1}$ Institute for Neurological Discoveries, Departments of ${ }^{2}$ Molecular and Integrative Physiology, ${ }^{3}$ Pathology and Laboratory Medicine, and ${ }^{4}$ Otolaryngology

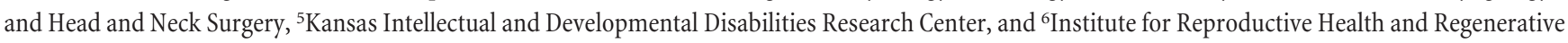 \\ Medicine, University of Kansas Medical Center, Kansas City, Kansas 66160
}

Peripheral axons are structurally plastic even in the adult, and altered axon density is implicated in many disorders and pain syndromes. However, mechanisms responsible for peripheral axon remodeling are poorly understood. Physiological plasticity is characteristic of the female reproductive tract: vaginal sensory innervation density is low under high estrogen conditions, such as term pregnancy, whereas density is high in low-estrogen conditions, such as menopause. We exploited this system in rats to identify factors responsible for adult peripheral neuroplasticity. Calcitonin gene-related peptide-immunoreactive sensory innervation is distributed primarily within the vaginal submucosa. Submucosal smooth muscle cells express bone morphogenetic protein 4 (BMP4). With low estrogen, BMP4 expression was elevated, indicating negative regulation by this hormone. Vaginal smooth muscle cells induced robust neurite outgrowth by cocultured dorsal root ganglion neurons, which was prevented by neutralizing BMP4 with noggin or anti-BMP4. Estrogen also prevented axon outgrowth, and this was reversed by exogenous BMP4. Nuclear accumulation of phosphorylated Smad1, a primary transcription factor for BMP4 signaling, was high in vagina-projecting sensory neurons after ovariectomy and reduced by estrogen. BMP4 regulation of innervation was confirmed in vivo using lentiviral transduction to overexpress BMP4 in an estrogen-independent manner. Submucosal regions with high virally induced BMP4 expression had high innervation density despite elevated estrogen. These findings show that BMP4, an important factor in early nervous system development and regeneration after injury, is a critical mediator of adult physiological plasticity as well. Altered BMP4 expression may therefore contribute to sensory hyperinnervation, a hallmark of several pain disorders, including vulvodynia.

\section{Introduction}

Peripheral target organs can undergo significant changes in innervation associated with both adaptive and maladaptive events. Certain pathophysiological conditions, such as neuropathies, have long been associated with reductions in axon numbers (Lauria et al., 2005), whereas more recent studies show that increased innervation density (hyperinnervation) can also contribute to pathological conditions, such as sudden cardiac death after myocardial ischemia (Cao et al., 2000; Hasan et al., 2006), musculo-skeletal pain in vitamin D deficiency (Tague et al., 2011), and inflammatory pain (Bohm-Starke et al., 1999; Chakrabarty et al., 2011). These findings underscore the mal-

Received April 6, 2012; revised Nov. 6, 2012; accepted Nov. 12, 2012.

Author contributions: A.B., M.A.K.R., H.S., and P.G.S. designed research; A.B. performed research; M.A.K.R. and H.S. contributed unpublished reagents/analytic tools; A.B. and P.G.S. analyzed data; A.B. and P.G.S. wrote the paper.

This work was supported by National Institutes of Health National Institute of Child Health and Human Development Grant R01HD049615 with core support from P30HD002528. We thank Dr. Anuradha Chakrabarty and Dr. Dora Krizsan-Agbas for technical guidance and the staff of the Kansas Intellectual and Developmental Disabilities Research Center for facilitating these studies, including Dr. Don Warn for microscopy and imaging assistance and Jing Huang for histology services.

The authors declare no competing financial interests.

Correspondence should be addressed to Dr. Peter G. Smith, University of Kansas Medical Center, Kansas Life Sciences Innovation Center, 3901 Rainbow Boulevard, Kansas City, KS 66160. E-mail: psmith@kumc.edu.

DOI:10.1523/JNEUROSCI.1704-12.2013

Copyright $\odot 2013$ the authors $\quad 0270-6474 / 13 / 331050-12 \$ 15.00 / 0$ leability of peripheral axons under pathophysiological conditions in the adult organism.

Changes in peripheral innervation also occur physiologically in the mature organism as it adapts to demands incurred as a result of normal activities. This is particularly true for targets that must make substantial and sometimes rapid adjustments in structure and function. Perhaps some of the most vivid examples are those associated with female reproductive functions. For example, the uterus undergoes rapid denervation coincident with the sexually receptive phase of the estrous cycle, which is thought to be important in providing an environment conducive to implantation of the conceptus. Innervation is again depleted during pregnancy, contributing to uterine quiescence before hormonally regulated parturition (Latini et al., 2008), followed by reinnervation (Brauer, 2008). Similarly, vaginal innervation is reduced at term pregnancy, which may facilitate delivery by diminishing vaginal smooth muscle tone and promoting maternal well-being by reducing numbers of local pain-sensing terminals (Liao and Smith, 2011).

Estrogen appears to be a dominant factor driving reproductive tract neuroplasticity. Vaginal innervation by presumptive nociceptor axons containing calcitonin gene-related peptide (CGRP)immunoreactivity (IR) is increased in rats under low estrogen conditions after ovariectomy (an animal model of menopause) and reduced by elevating serum estrogen by exogenous administration of $17 \beta$-estradiol (Ting et al., 2004; Liao and Smith, 2011). In hu- 

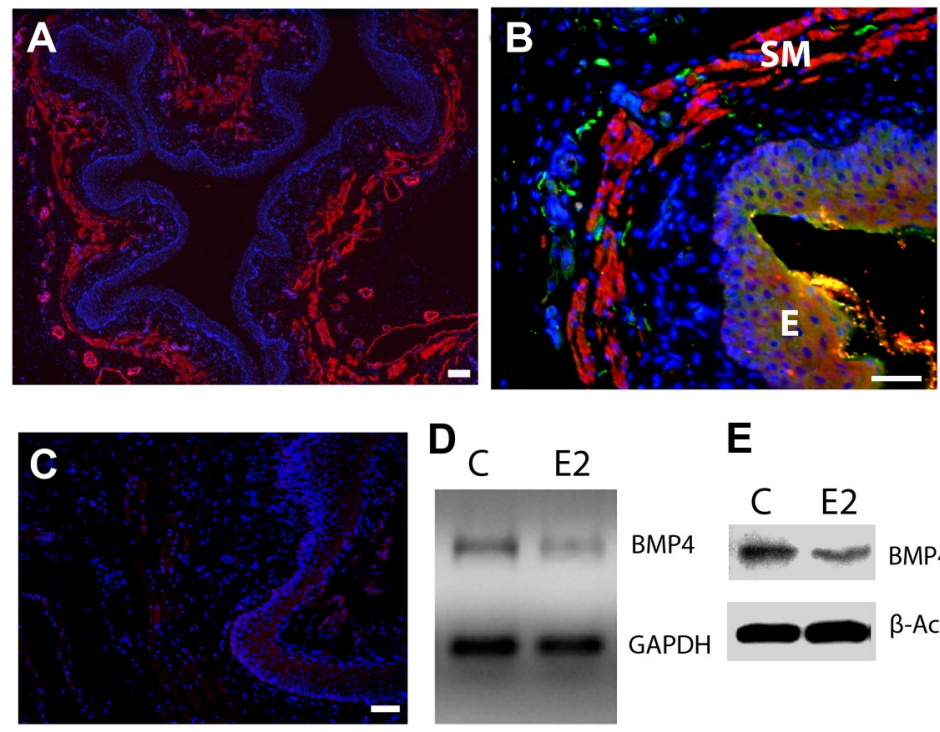

E
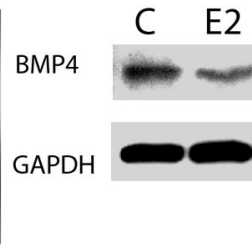

Figure 1. BMP4 expression and regulation in the adult rat vagina. A, Low-magnification image shows gross histology of the vagina in cross-section. $\alpha$-Smooth muscle actin-IR reveals the submucosal smooth muscle layer (red), which lies beneath the epithelium demarcated by the dense aggregation of DAPI-stained nuclei (blue). B, BMP4-IR (red) is expressed almost exclusively within smooth muscle (SM) lying beneath the epithelium (E), and this corresponds to the location of most peripherin-positive axons (green). C, Preabsorption of the BMP4 antibody with an excess of mouse recombinant BMP4 eliminated staining of vaginal tissues. Scale bars, $50 \mu \mathrm{m}$. D, Submucosal vaginal tissue explants cultured for $24 \mathrm{~h}$ with $20 \mathrm{~nm}$ estrogen (E2) show reduced BMP4 gene expression by RT-PCR relative to GAPDH compared with untreated controls (C). $E$, In vivo treatment of OVX rats for $7 \mathrm{~d}$ with estrogen also reduced BMP4 protein levels relative to $\beta$-actin as assessed by immunoblot.

mans, systemic estrogen replacement therapy also reduces vaginal innervation density in postmenopausal women, and this effect is more robust when estrogen is applied topically (Griebling et al., 2012), implying a direct effect on vaginal tissue. It therefore appears that declining estrogen levels are associated with increased outgrowth by vaginal nociceptor axons.

Axon outgrowth in the adult is believed to require reactivation of certain transcriptional programs that are typically quiescent in mature neurons. For example, the transcription factor Smad1 is normally expressed at very low levels in intact dorsal root ganglion (DRG) sensory neurons but is markedly upregulated in association with regeneration after axonal injury (Zou et al., 2009). Smad1 is regulated by bone morphogenetic protein 4 (BMP4), a member of the TGF $\beta$ superfamily of cytokines/morphogens (Miyazono et al., 2010). A possible role for the BMP4/ Smad1 signaling pathway in reproductive tract axon remodeling is supported by reports that BMP4 is synthesized by vaginal tissues (Cai, 2009) and negatively regulated by estrogen (Chen et al., 2009). In the present study, we investigated whether BMP4 mediates estrogen-driven plasticity of peripheral sensory innervation.

\section{Materials and Methods}

All animal protocols and procedures were approved by the Kansas University Medical Center Animal Care and Use Committee and were in accordance with the National Institutes of Health Guidelines for the Care and Use of Laboratory Animals.

Immunohistochemistry. Female Sprague Dawley rats were surgically ovariectomized (OVX) at 8 weeks of age according to established methods (Zoubina et al., 2001). After $7 \mathrm{~d}$, rats ( $n=4$ per group) received neck scruff subcutaneous implants of SILASTIC tubing (inner diameter, 1.575; outer diameter, $3.175 \mathrm{~mm}$; length, $20 \mathrm{~mm}$; volume, $170 \mu \mathrm{l}$ ) containing sesame oil vehicle with or without $180 \mu \mathrm{g} / \mathrm{ml} 17 \beta$-estradiol (Sigma) (Ström et al., 2008), which raises serum estrogen levels in OVX rats from $<15 \mathrm{pg} / \mathrm{ml}$ to $\sim 80 \mathrm{pg} / \mathrm{ml}$ (high physiological levels similar to
BMP4

proestrus and term pregnancy). Seven days later, animals were killed by thoracotomy under isoflurane anesthesia, and vagina and DRG were harvested and fixed by overnight immersion in Zamboni's fixative at $4^{\circ} \mathrm{C}$ and cryosectioned at $10 \mu \mathrm{m}$ as described previously (Ting et al., 2004; Tague and Smith, 2011). In groups used to analyze pSmad1 expression, rats received a single subcutaneous injection of 10 $\mu \mathrm{g} / \mathrm{kg} 17 \beta$-estradiol, which produces a rapid rise in serum estrogen (Zoubina et al., 2001), or sesame oil vehicle ( $n=3$ per group), and $24 \mathrm{~h}$ later L6-S1 DRGs were removed, fixed in neutral buffered Formalin, and cryosectioned.

Sections were immunostained overnight for peripherin (1:400, rabbit antiserum; 1:500, chicken antiserum; Millipore), protein gene product 9.5 (PGP9.5; 1:1000, rabbit antiserum; Serotech), tyrosine hydroxylase (TH; 1:200, rabbit antiserum, Millipore), CGRP (1:400, sheep antiserum; Biomol), enhanced green fluorescent protein (EGFP; 1:750, chicken antiserum; Aves), BMP4 (1:100, mouse monoclonal antibody; Millipore), bone morphogenetic protein receptor type 1A (BMPR1A; 1:100, rabbit antiserum; Santa Cruz Biotechnology), BMPR2 (1:100, goat antiserum; Santa Cruz Biotechnology), $\alpha$-smooth muscle actin (Cy3conjugated mouse antiserum; Sigma), and phosphorylated Smad1 (pSmad1; 1:200, rabbit monoclonal antibody; Cell Signaling Technologies). Secondary antibodies included donkey anti-rabbit Cy3 at 1:200 (Jackson ImmunoResearch), donkey anti-mouse Cy3 (1:200; Jackson ImmunoResearch), donkey anti-rabbit Alexa Fluor 488 (1:750; Invitrogen), donkey antirabbit Alexa Fluor 647 (1:500; Invitrogen), donkey anti-chicken Dylight 488 (1:750; Invitrogen), donkey anti-goat Cy3 (1:200; Jackson ImmunoResearch), goat anti-rabbit Cy3 (1:200; Jackson ImmunoResearch), and donkey anti-sheep Cy3 (1:200; Jackson ImmunoResearch). Antibodies have been characterized previously by our laboratory and others (Abir et al., 2008; Clarke et al., 2010; Tague and Smith, 2011; Tague et al., 2011) and include omissions of primary and secondary antibodies and preabsorption of anti$\mathrm{BMP} 4$ with recombinant mouse BMP4 at $500 \mathrm{ng} / \mathrm{ml}$ for 45 min before staining.

Retrograde tracing. Four days after OVX, rats were anesthetized by isoflurane inhalation. Using a Hamilton syringe and 30 gauge needle, recombinant cholera toxin-B (CTB) conjugated to Alexa Fluor 488 (2 $\mu \mathrm{g} / \mu \mathrm{l}$ in PBS; Life Technologies) was injected submucosally at four sites equidistant along the vaginal circumference $(2.5 \mu \mathrm{l} /$ site; $10 \mu \mathrm{l}$ total $)$ at midvaginal level. Two days after CTB injection, rats received either a single subcutaneous injection of $10 \mu \mathrm{g} / \mathrm{kg} 17 \beta$-estradiol (which produces a rapid rise in serum estrogen; Zoubina et al., 2001) or sesame oil vehicle ( $n=5$ per group). Twenty-four hours later, rats were deeply anesthetized with ketamine-xylazine and perfused transcardially with heparinized PBS, followed by ice-cold 4\% formaldehyde in PBS. L6, S1, and S2 DRGs, which are reported to give rise to vaginal innervation (Berkley et al., 1993), were harvested, cryosectioned at $14 \mu \mathrm{m}$, immunostained for BMPR1A, BMPR2, and pSmad1, and costained for peripherin. Randomized images from six to eight sections per animal were acquired, and percentages of labeled neurons expressing specific markers were assessed in $\sim 200$ retrogradely labeled neurons per rat.

Flow cytometry. L6-S2 DRG were harvested aseptically from 8-weekold female rats, diced in ice-cold L-15 medium with $3 \%$ glucose, incubated in $1 \mathrm{mg} / \mathrm{ml}$ collagenase and $2.5 \mathrm{U} / \mathrm{ml}$ dispase (Worthington) in HBSS for $40 \mathrm{~min}$, and triturated using fire-polished glass pipettes in L-15glucose with $10 \%$ FBS. Cells were filtered through a $100 \mu \mathrm{m}$ mesh and centrifuged through a Percoll gradient column to remove debris. The washed pellet was resuspended, fixed in cold $2 \%$ formaldehyde for $1 \mathrm{~h}$, and washed in PBS with Triton X-100 (Sigma) on ice. Cells were immunostained 
for $1 \mathrm{~h}$ for peripherin (detected with donkey antichicken Alexa Fluor 488) and BMPR1A (donkey anti-rabbit Cy3), fixed in $1 \%$ formaldehyde, and washed. Fluorescence-activated cell sorting (FACS) was conducted using a BD Aria system, with cells categorized based on their fluorescence intensity in arbitrary units.

PCR and immunoblots. Effects of estrogen on BMP4 gene expression were assessed in vaginal tissue ex vivo. Vaginas from 8-week-old OVX rats were cut along the length of the lumen and everted, and the mucosal surface was gently scraped to remove the epithelium. Vaginal wall explants $\left(1 \mathrm{~mm}^{3}\right)$ containing smooth muscle and adventitia were cultured in separate wells of a 24well plate in DMEM/F-12 medium for $24 \mathrm{~h}$ with or without $20 \mathrm{~nm} 17 \beta$-estradiol and homogenized in Trizol (Invitrogen) for RNA isolation. cDNA was synthesized from $1 \mu \mathrm{g}$ of total RNA using iScript Reverse Transcriptase kit (Bio-Rad). Semi-quantitative RT-PCR was performed for 30 cycles with $55^{\circ} \mathrm{C}$ annealing temperature using primers for BMP4 (forward, GAGCCTTTCCAG CAAGTTTGTTC; reverse, GTTCTCCAGATG TTCTTCGTGATG; product size, $487 \mathrm{bp}$ ) and GAPDH (forward, CTCTACCCACGGCAAG TT; reverse, CTCAGCACCAGCATCACC; product size, $120 \mathrm{bp}$ ), and products were separated on a $1 \%$ agarose gel for densitometric analysis.

To assess BMP4 protein levels, Western blots were performed from tissue collected from OVX rats with or without estrogen supplementation in vivo, as described above. Vaginal submucosa was homogenized in RIPA buffer, and $40 \mu \mathrm{g}$ of total protein per well was separated on a $12 \%$ polyacrylamide gel, transferred to a PVDF membrane, probed with antiBMP4 (mouse monoclonal antibody, 1:500; Millipore), and reprobed for $\beta$-actin (1:1000; Sigma). For evaluating BMP4 overexpression via lentiviral transduction, $24 \mathrm{~h}$ conditioned medium was collected from stably infected HEK293T cells. From equal volumes of conditioned medium, total protein was precipitated by TCA-acetone. Equal amounts of resuspended protein were used for immunoblot and probed for BMP4 as described above.

Neuron and smooth muscle cultures. L6-S2 DRGs from 5-week-old rats were harvested as above. To assess neurite outgrowth in response to BMP4, neurons equivalent to one-half of a DRG per well were plated onto collagenprecoated 24-well plates (BD Biosciences) in serum-free Neurobasal A medium with B27 supplement (Invitrogen) and 10 or $50 \mathrm{ng} / \mathrm{ml}$ mouse recombinant BMP4 (PeproTech) and cultured for $48 \mathrm{~h}$, with neurite quantification as described below. For confocal imaging, some neuronal cultures were grown in defined medium for $48 \mathrm{~h}$ on laminin/poly-D-lysine (Invitrogen/Sigma-Aldrich) coated glass coverslips, fixed in 4\% PFA, and immunostained for BMPR1A, BMPR2, and peripherin.

For neuron-smooth muscle cocultures, vaginal tissue from 8 -week-old rats was harvested in ice-cold L-15 medium and stripped of epithelium with a sterile scalpel blade. Portions of smooth muscle were dissected, diced, and im-
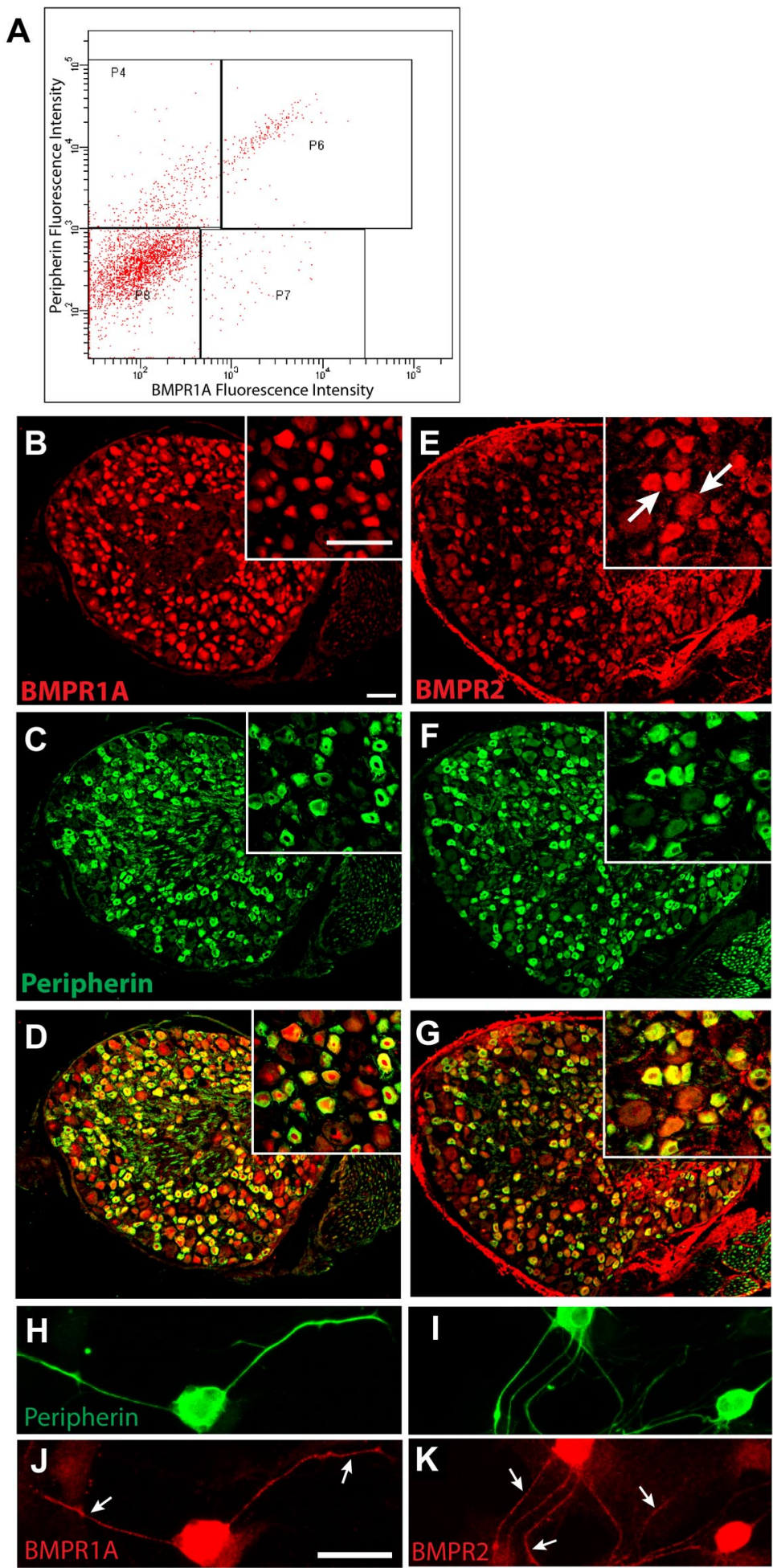

Figure 2. BMP receptors are expressed in $L 6-S 2$ sensory neurons. $A$, FACS of dissociated DRG cells immunolabeled for BMPR1A (Cy3) and peripherin (Alexa Fluor 488) reveal high levels of BMPR1A fluorescence intensity in cells displaying high peripherin fluorescence intensity (P6). Other populations include peripherin-negative cells with high BMPR1A expression (P7), peripherinpositive cells with low BMPR1A expression (P4), and cells negative for either marker (P8). B, Immunostaining of an L6 DRG section shows that BMPR1A protein is widely distributed; inset is a higher-power image showing BMPR1A localized predominantly within neurons. $C$, Distribution of peripherin immunostaining in the section shown in $\boldsymbol{B} . \boldsymbol{D}, \mathrm{A}$ merged image shows that BMPR1A-IR is present predominantly in peripherin-positive neurons. $E$, BMPR2 immunostaining shows wider localization across different neuronal subtypes. $\boldsymbol{F}$, Immunostaining reveals peripherin-expressing DRG neurons in $\boldsymbol{E}$. $\boldsymbol{G}$, Most peripherin-positive neurons show BMPR2-IR. $\boldsymbol{H}, \boldsymbol{I}$, Peripherin-immunoreactive neurons in dissociated DRG culture. Immunostaining for BMPR1A $(\boldsymbol{J})$ and BMPR2 $(\boldsymbol{K})$ show that both receptors are present throughout the axons (arrows) as well as the cell body. Scale bars, $50 \mu \mathrm{m}$. 

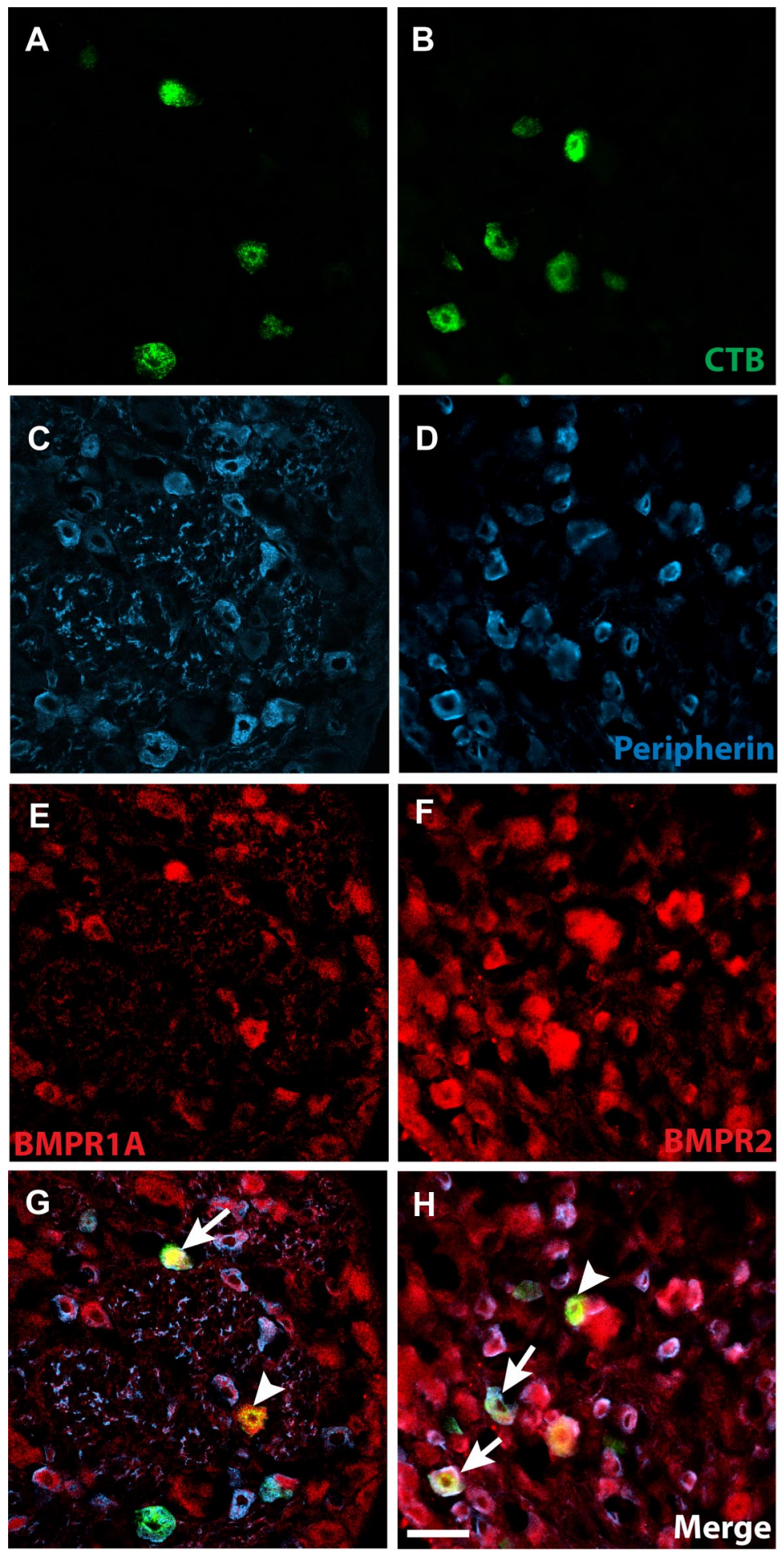

Figure 3. Vagina-projecting neurons express BMP4 receptors. $A, B$, Neurons projecting specifically to the vaginal submucosa were labeled after Alexa Fluor-488-conjugated recombinant CTB injection, as shown here in an $\$ 1$ DRG. C, D, Retrogradely labeled neurons frequently display peripherin-IR. $\boldsymbol{E}, \boldsymbol{F}$, Vagina-projecting neurons exhibit IR for both BMPR1A and BMPR2. G, H, Arrows indicate CTB-labeled, peripherin-positive neurons expressing BMPR. Arrowheads indicate CTB-labeled, peripherin-negative neurons expressing BMPR. Scale bar, $50 \mu \mathrm{m}$ (for all panels).

mersed in L-15 medium containing $2 \mathrm{mg} / \mathrm{ml}$ collagenase (SigmaAldrich) on ice for $30 \mathrm{~min}$. Tissue was incubated at $37^{\circ} \mathrm{C}$ for $30 \mathrm{~min}$ and then triturated using fire-polished glass pipettes while adding medium containing $10 \%$ FBS to neutralize the collagenase. The suspension was passed through $100 \mu \mathrm{m}$ mesh to remove debris and centrifuged at $300 \times$ $g$ for $7 \mathrm{~min}$, and the pellet was resuspended in DMEM-10\% FBS. Cells were plated onto a collagen-coated $35 \mathrm{~mm}$ dishes (BD Bioscience), incubated at $37^{\circ} \mathrm{C}$ in $5 \% \mathrm{CO}_{2}$ for $48 \mathrm{~h}$, and then divided. To control for nonspecific interactions between neurons and cocultured cells, in some experiments, we substituted rat embryonic fibroblasts cultured at more than seven passages for smooth muscle cells.

L6-S2 DRG from female rats aged $35 \mathrm{~d}$ were harvested aseptically and dissociated as described above. Neurons equivalent to one-half ganglion per well were plated onto confluent layers of smooth muscle cells grown on collagen-coated 48-well plates (BD Biosciences). Cells were cocultured in the presence or absence of different amendments, including $17 \beta$-estradiol (20 nM), noggin ( $250 \mathrm{ng} / \mathrm{ml}$; PeproTech), anti-BMP4 (500 ng/ml; PeproTech), and BMP4 (10 ng/ml; PeproTech). After 48 h, cocultures were fixed with $4 \%$ formaldehyde and washed with PBS. Cultures were immunostained for peripherin and in some cases for $\alpha$-smooth muscle actin.

In some experiments, smooth muscle cells were prepared as above and initially grown in transwells (Corning) for $24 \mathrm{~h}$. These were then transferred to 24-well plates in which dissociated DRG neurons had been seeded on collagen. Transwell cocultures were maintained for $48 \mathrm{~h}$ in the presence or absence of anti-BMP4, fixed, and immunostained as above.

To quantify neurite outgrowth, six to eight random images per well of peripherin-expressing neurons were captured using a $20 \times$ objective $(412 \times 330 \mu \mathrm{m}$ field size $)$. Neurite area was measured using a stereological grid (AnalySis version 3.2; Soft Imaging System) superimposed over each image as described previously (Chakrabarty et al., 2008). Numbers of line intersections overlying stained neurites were divided by total intersections within the field and multiplied by total field area. Neurite area was divided by the number of neurons with at least one neurite within the field, and all values in a well were averaged and presented as neurite area per neuron.

Lentivirus production and injections. Fulllength cDNA of rat BMP4 downstream to a CMV promoter was cloned into the FG12 lentiviral vector (Addgene) between $\mathrm{XbaI}$ and PacI restriction sites. The vector carries an EGFP reporter under a ubiquitin-C promoter. Third-generation lentiviral packaging with pMDLg/RRE, pRSV-Rev, and pMD2.G (Addgene) was used to synthesize lentiviral particles for BMP4 and EGFP-only vectors. HEK293T cells were plated in six-well plates at $60-80 \%$ confluence and transfected with the vector carrying the gene of interest or EGFP alone and all the three packaging plasmids using Lipofectamine 2000 (Invitrogen) in OptiMEM medium (Invitrogen). Medium was changed $12 \mathrm{~h}$ later with OptiMEM-5\% FBS, and supernatant was collected every $24 \mathrm{~h}$ for $2-3 \mathrm{~d}$. Viral particles were concentrated from the supernatant by ultracentrifugation in sealed tubes for $2 \mathrm{~h}$ at 35,000 rpm and resuspended in sterile PBS. Lentiviral titers were measured using the Lentivirus qPCR titer kit (Applied Biological Materials).

OVX rats were anesthetized with ketamine and xylazine (70 and 6 $\mathrm{mg} / \mathrm{kg}$ ) and injected intravaginally using a 30 gauge needle attached by polyethylene tubing to a Hamilton syringe. Injections of lentivirus ex- 
pressing BMP4 $(n=4)$ or EGFP alone $(n=4)$ were made at four intravaginal sites (corresponding to 3, 6, 9, and 12 o'clock), and a total volume of $10 \mu \mathrm{l}$ containing $1 \times 10^{8}$ viral particles was deposited into submucosal regions corresponding to the location of the vaginal smooth muscle. At the time of injection, rats were implanted with capsules containing sesame oil with or without $17 \beta$-estradiol (Ting et al., 2004; Ström et al., 2008). Seven days after injections and implantations, rats were killed, and vaginal tissues were harvested and fixed in Zamboni's solution. Tissues were sectioned at $14 \mu \mathrm{m}$ and immunostained for PGP 9.5, peripherin, CGRP, TH, BMP4, or EGFP. Innervation density was measured in images captured from regions corresponding to the injection sites as identified by BMP4 and EGFP expression and from adjacent non-injected sites that did not show virally transduced gene expression. Eight to 14 images were captured from injection and from adjacent sites for each animal, and axonal area within each $412 \times 330$ $\mu \mathrm{m}$ field was determined by thresholding (AnalySis Software) and averaged (Ting et al., 2004).

Statistical analyses. All values are presented as mean \pm SEM. Comparisons between groups were made using Student's $t$ test, one-way ANOVA, or two-way ANOVA with post hoc comparisons by Student-Newman-Kuels tests for normally distributed data and MannWhitney rank-sum test for nonparametric analysis. Paired $t$ tests were used to compare innervation densities in injected and noninjected sites within the same animals in the lentiviral studies. Differences were considered significant at $p \leq 0.05$.

\section{Results}

BMP4 is expressed in adult rat vagina BMP4 is an essential morphogen regulating vaginal development and is expressed in the early postnatal period (Cai, 2009). However, BMP4 expression has not been described in mature vagina. The vagina of the 8-week-old rat consists of thickened mucosal epithelium surrounded by connective tissue containing a distinct smooth muscle layer (Fig. 1A). Immunostaining showed abundant BMP4 labeling primarily confined to the smooth muscle layer (Fig. 1B), which was eliminated by antibody preabsorption with recombinant BMP4 protein (Fig. 1C). The smooth muscle layer also contains presumptive nociceptor innervation (Ting et al., 2004), and immunostaining revealed many axons immunoreactive for peripherin (Fig. 1B), an intermediate filament protein localized to axons and somata of small-to-mediumdiameter neurons, including DRG nociceptors (Ferri et al., 1990; Goldstein et al., 1991; Fornaro et al., 2008).

\section{Estrogen downregulates BMP4 expression in vaginal smooth muscle}

Vaginal cells, including smooth muscle cells, express estrogen receptors that influence structure and function by altering gene
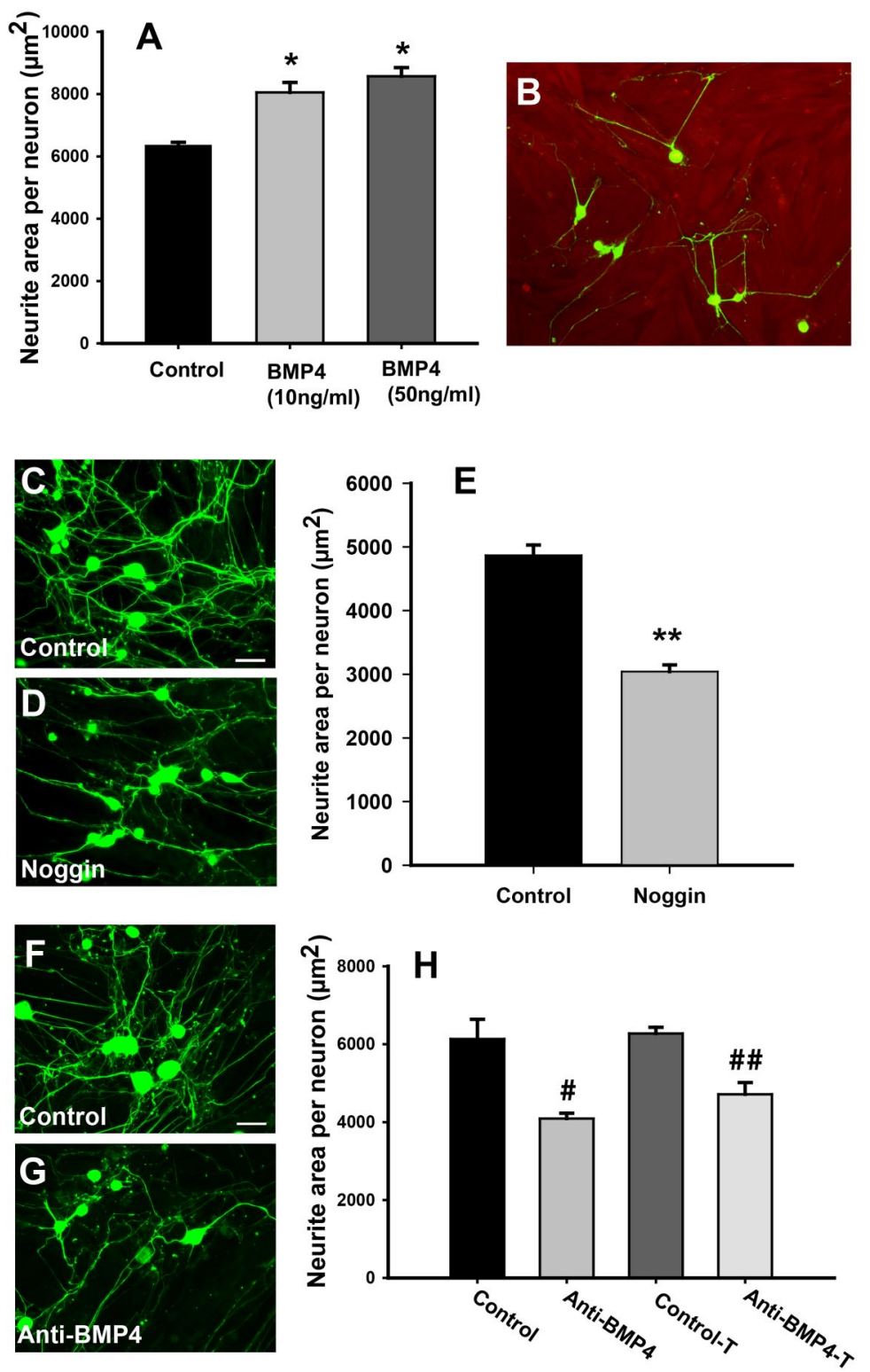

Figure 4. Target-derived BMP4 promotes sensory neurite outgrowth. $\boldsymbol{A}$, Dissociated DRG neurons grown on collagen-coated plates showed increased neurite outgrowth in the presence of 10 or $50 \mathrm{ng} / \mathrm{ml} \mathrm{BMP4}$ ( ${ }^{*} p \leq 0.007$ ). $\boldsymbol{B}$, Vaginal smooth muscle cells immunostained for $\alpha$-smooth muscle actin (red) were grown on collagen-coated plastic. DRG neurons immunostained for periph(green) were plated on smooth muscle cells, and most extended neurites that made contacts with muscle cells at $48 \mathrm{~h}$. $\boldsymbol{C}$ Vehicle-treated cocultures immunostained for peripherin showed many neurites. D. Cocultures treated with noggin ( $250 \mathrm{ng} / \mathrm{ml})$ had fewer neurites. $\boldsymbol{E}$, Quantitative analysis confirmed a reduction in neurite outgrowth per neuron in noggin-treated cocultures $\left({ }^{* *} p=0.001\right)$. $\boldsymbol{F}$, Neurites elaborated by neurons grown directly on smooth muscle cocultures (Control) are reduced by the addition of a BMP4 function-neutralizing antibody $\left({ }^{\#} p=0.005 ; \boldsymbol{G}, \boldsymbol{H}\right)$. Anti-BMP4 was equally effective in reducing axon outgrowth when smooth muscle cells were grown in transwell inserts ( $\boldsymbol{H}$, Control-T, Anti-BMP4-T; $\left.{ }^{\#} p=0.004\right)$. Scale bars, $50 \mu \mathrm{m}$.

expression (MacLean et al., 1990; Forsberg, 1995; Mowa and Iwanaga, 2000; Giraldi et al., 2002). To assess effects of estrogen on BMP4 expression in mature rat vaginal tissue, we performed RTPCR on vaginal submucosal explants cultured for $24 \mathrm{~h}$ in the presence or absence of $20 \mathrm{~nm}$ estrogen. Semiquantitative RT-PCR showed that, relative to GAPDH expression, estrogen downregulated BMP4 mRNA in the vaginal submucosal smooth muscle (Fig. 1D)

We evaluated changes in BMP4 protein content in 8-week-old OVX rats implanted with $17 \beta$-estradiol-releasing capsules for $7 \mathrm{~d}$. In Western blot analysis, vaginal BMP4 protein levels normalized to $\beta$-actin were reduced in animals receiving estrogen compared with 

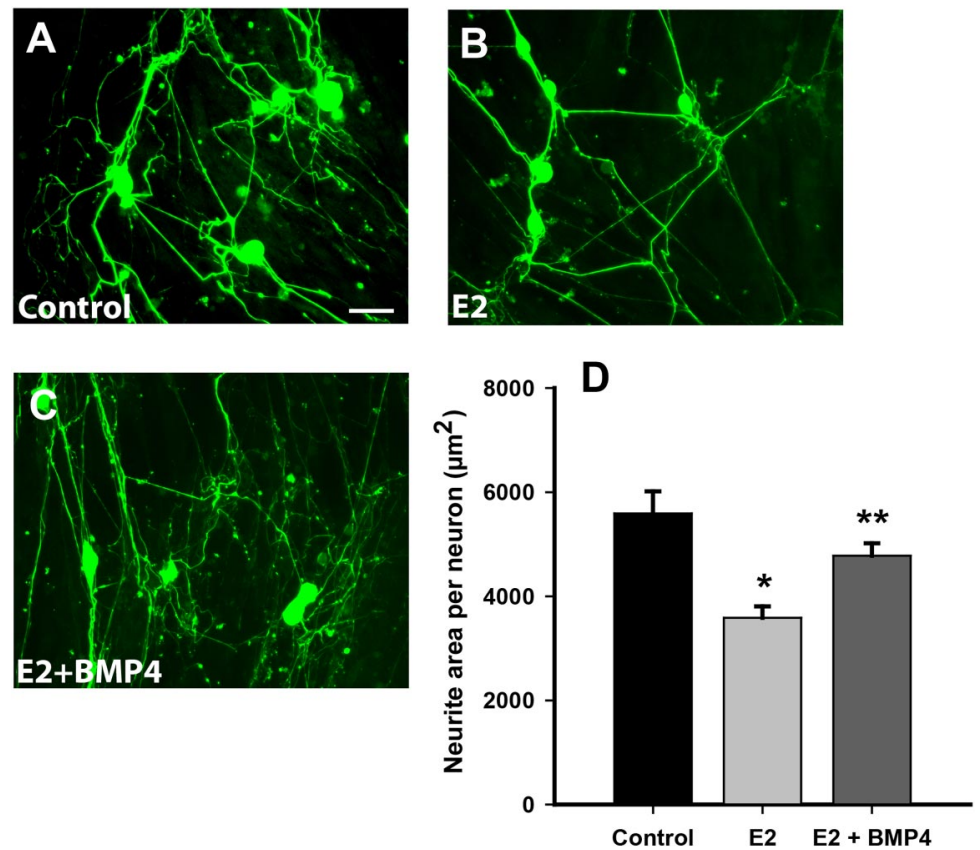

Figure 5. Neurite outgrowth in cocultures is downregulated by estrogen and rescued by exogenous BMP4. $\boldsymbol{A}$, Smooth muscle cells (unstained) were grown for $72 \mathrm{~h}$, on which dissociated sensory neurons (green) were cultured for $48 \mathrm{~h}$. Scale bar: $\boldsymbol{A}-\boldsymbol{C}, 50 \mu \mathrm{m}$. $\boldsymbol{B}$, When smooth muscle cells were grown in the presence of $2 \times 10^{-8} \mathrm{M} 17 \beta$-estradiol, neurite outgrowth appeared to be reduced. C, Addition of $10 \mathrm{ng} / \mathrm{ml}$ recombinant BMP4 appeared to increase numbers of neurites. D, Quantitative analysis showed that neurite outgrowth per neuron was reduced by estrogen (E2) pretreatment ( ${ }^{*} p=0.001$ vs control), and the decrease was abrogated by BMP4 ( ${ }^{\#} p=0.004$ vs E2). There was no significant difference between control and E2 + BMP4.

vehicle controls (Fig. 1E), indicating that estrogen reduces both BMP4 mRNA and protein.

\section{Adult DRG neurons express BMP receptors}

BMP4 acts by binding to cell surface receptors that are typically heterodimers consisting of BMPR2 and BMPR1A or BMPR1B. Cervical and thoracic DRG sensory neurons express BMPR2 and predominantly BMPR1A (but not BMPR1B) during development (Zhang et al., 1998), but their presence in more caudal ganglia and persistence into adulthood are unclear. To assess $\mathrm{BMP}$ receptor presence and distribution, we performed FACS of 8-week-old rat dissociated DRGs from L6-S2, which innervate the rat vagina (Berkley et al., 1993). FACS revealed a substantial cell population with intense fluorescence for both peripherin and BMPR1A (Fig. 2A, P6), confirming the presence of this receptor in the peripherin-immunoreactive population of neurons. A second population of peripherin-positive neurons showed lower levels of BMPR1A expression (P4). Additional cells showed low peripherin and low-to-high BMPR1A-IR (P8, P7).

We examined DRG sections to further assess BMP4 receptor localization. BMPR1A-IR was observed primarily in peripherinexpressing neurons, with smaller numbers of peripherin-positive neurons lacking BMPR1A-IR and a few peripherin-negative, large-diameter neurons expressing the receptor (Fig. $2 B-D$ ); preliminary studies confirmed a paucity of BMPR1B staining (data not shown). Immunostaining for BMPR2 showed that this coreceptor was also enriched in peripherin-immunoreactive neurons (Fig. 2E-G). BMPR2-IR was observed additionally in largediameter neurons, although the signal intensity was typically less than that of peripherin-positive neurons.

We assessed the distribution of BMP4 receptors within peripherin-positive neurons in culture (Fig. $2 H, I$ ). Both
BMPR1A and BMPR2 showed strong immunostaining throughout the soma and axons (Fig. $2 J, K$ ).

To confirm that small-diameter neurons projecting to the vagina express BMPR1A and BMPR2 receptors, we immunostained sections of DRGs $3 \mathrm{~d}$ after CTB injection of the vaginal submucosa in OVX rats with or without estrogen supplementation. CTB-labeled neurons were present bilaterally in L6-S2 DRGs (Fig. $3 A, B)$. Analysis of peripherinimmunostained sections revealed that $61 \pm 3 \%$ of CTB-labeled neurons were immunoreactive for this smalldiameter neuron marker (Fig. 3C,D). BMPR1A-IR was associated with many CTB-labeled cells (Fig. 3E); quantitative analysis revealed that more than twothirds of vagina-projecting neurons expressed BMPR1A (70 $\pm 4 \%$ in OVX, $67 \pm 4 \%$ after estrogen); most of these were also peripherin positive (Fig. 3G; $63 \pm 3 \%$ in OVX, $54 \pm 12 \%$ after estrogen). BMPR2-IR also was observed in a majority CTB-labeled neurons (Fig. $3 F$; $81 \pm 3 \%$ in OVX, $71 \pm 7 \%$ after estrogen), with most of these immunoreactive for peripherin (Fig. $3 H ; 64 \pm 4 \%$ in OVX, $64 \pm 4 \%$ after estrogen). Estrogen status did not influence BMPR expression.

\section{BMP4 mediates smooth muscle-induced sensory neurite outgrowth}

Our findings show that DRG sensory neurons, including those projecting to the vagina, express BMP4 receptors and that vaginal target cells synthesize BMP4 more robustly in low-estrogen conditions. Accordingly, reduced BMP4 protein levels could contribute to vaginal axon pruning that occurs when estrogen levels are elevated, as in term pregnancy (Liao and Smith, 2011) and after exogenous hormone replacement (Ting et al., 2004; Griebling et al., 2012).

We tested the responsiveness to BMP4 of primary sensory neurons plated on collagen in defined media. The addition of 10 $\mathrm{ng} / \mathrm{ml}$ recombinant BMP4 increased axon outgrowth relative to that in control media (Fig. 4A); outgrowth was not increased further at $50 \mathrm{ng} / \mathrm{ml}$. To delineate whether BMP4 plays a functional role in target regulation of sensory innervation, we cultured dissociated DRG neurons atop near-confluent vaginal smooth muscle cells. Individual neurons elaborated neurite arbors that made multiple contacts with smooth muscle cells (Fig. $4 B)$. We first determined whether members of the BMP family contribute to smooth muscle-induced sprouting by treating cultures with noggin, an endogenous inhibitor of BMP4 (McMahon et al., 1998; Sela-Donenfeld and Kalcheim, 1999). Noggin at concentrations of $250 \mathrm{ng} / \mathrm{ml}$ appeared to decrease neurite outgrowth relative to control cultures at $48 \mathrm{~h}$ (Fig. $4 C, D$ ), and this was confirmed by quantifying neurite area per viable neuron, in which noggin reduced outgrowth by $38 \%$ (Fig. $4 E$ ). When adult DRG neurons were cultured under the same conditions but in the absence of smooth muscle cells, noggin failed to alter neurite outgrowth (data not shown). These findings implicate BMPs in smooth muscle cell-mediated sensory neuronal sprouting. 

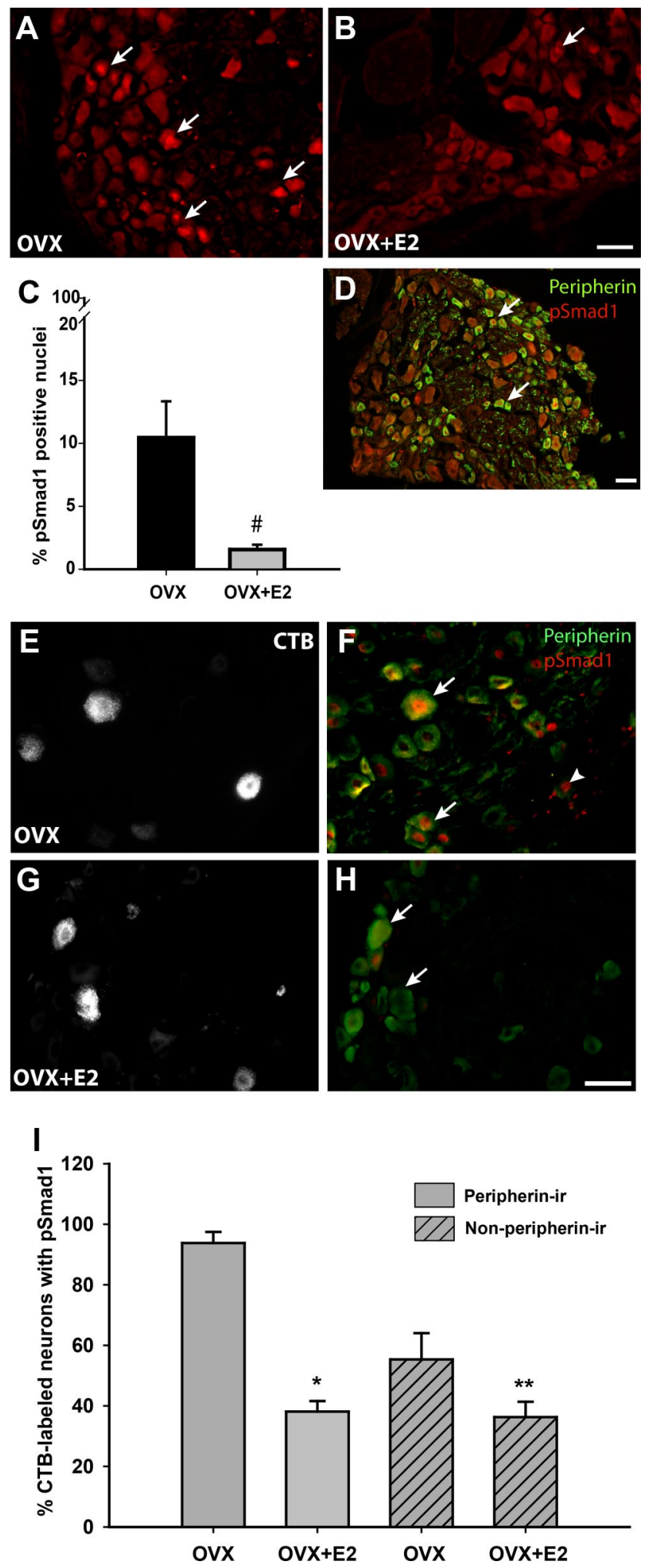

Figure 6. $\quad$ pSmad1 expression in DRG neurons is reduced after estrogen administration. $\boldsymbol{A}$, In vehicle-injected OVX rats, many nuclei show high levels of $\mathrm{pSmad1-IR} \mathrm{(arrows).} \mathrm{B,} \mathrm{At} 24 \mathrm{~h}$ after estrogen administration (OVX+E2), pSmad1-positive nuclei were observed infrequently. $\boldsymbol{C}$, Quantitative analysis confirms that numbers of $\mathrm{pSmad1-positive} \mathrm{nuclei} \mathrm{are} \mathrm{markedly} \mathrm{reduced}$ by estrogen administration $\left({ }^{*} p=0.038\right)$. $\boldsymbol{D}$, Double immunostaining for peripherin (green) and $\mathrm{pSmad1}$ (red) show that positive nuclei are frequently present in peripherin-positive neurons in the OVX rat. $\boldsymbol{E}$, Vaginal submucosal injection of CTB resulted in retrograde labeling of DRG neurons of OVX rats. $\boldsymbol{F}$, Several CTB-labeled neurons in this low-estrogen condition $(\boldsymbol{E})$ display nuclear pSmad1. Arrows points to peripherin-positive CTB-labeled neurons, and arrowhead shows a peripherin-negative CTB neuron. $G$, Vaginal CTB injection also labeled DRG neurons in
Although noggin is an effective endogenous inhibitor of BMP4, it can bind other members of the BMP family of proteins. To ensure that reduced neurite outgrowth observed with noggin is attributable to BMP4 neutralization, we used a functionneutralizing antibody directed specifically against BMP4. Relative to control cultures (Fig. $4 F$ ), BMP4 antibody reduced neurite outgrowth by $32 \%$ (Fig. $4 G, H$ ) but did not affect outgrowth by neurons cultured in the absence of smooth muscle (data not shown).

To confirm that the effects of the BMP4 function-neutralizing antibody are dependent on BMP4 synthesis by cocultured cells, we grew DRG neurons with rat embryonic fibroblasts, which are not believed to synthesize BMP4. The addition of anti-BMP4 to the culture medium did not alter neurite outgrowth $(6381 \pm 482$ $\mu \mathrm{m}^{2}$ control vs $6210 \pm 675 \mu \mathrm{m}^{2}$ anti-BMP4).

BMP4 is a secreted protein that influences its targets by way of diffusion. To ensure that BMP4 is acting as a secreted factor and not through any direct physical interaction between neuron and muscle, smooth muscle cells were cultured in transwell inserts that allow diffusible factors to reach neurons growing at the bottom of the culture well but prevent direct interactions. The addition of BMP4-neutralizing antibody to the culture medium was as effective in inhibiting outgrowth in these transwell cocultures as it was when neurons and smooth muscle were in direct contact (Fig. 4H).

Estrogen modulates smooth muscle-mediated axon growth in vitro via BMP4

Protein and RNA measurements show that estrogen reduces vaginal BMP4 expression. To assess whether estrogen modulates smooth muscle-induced outgrowth by way of BMP4, we grew vaginal smooth muscle cells in culture for $72 \mathrm{~h}$ in the presence or absence of $17 \beta$-estradiol. Adult DRG neurons were then plated over the near-confluent cultures in estrogen-free medium. Measurement of axon length per neuron showed that outgrowth at $48 \mathrm{~h}$ was significantly lower in the estrogen-pretreated muscle cell cultures compared with the untreated cultures (Fig. $5 A, B, D$ ).

We reasoned that, if reduced outgrowth in estrogenpretreated cultures is attributable to the reduction in BMP4 protein, then we should be able to reverse it by adding exogenous BMP4 to the estrogen pretreated cultures. We performed smooth muscle-DRG neuronal cocultures as above and added recombinant BMP4 to the medium in one estrogen pretreated group at the time of neuronal plating. Forty-eight hours after adding BMP4 to cultures pretreated with estrogen, outgrowth was increased significantly relative to cultures pretreated with estrogen alone and was statistically comparable with that seen in cocultures in which smooth muscle cells were not treated with estrogen (Fig. 5C,D).

\section{Estrogen-modulated axon plasticity is associated with changes in DRG pSmad1}

BMP4 binds to cell surface receptors that induce phosphorylation of cytoplasmic Smad1. pSmad1 travels to nucleus to regulate

OVX rats receiving estrogen. $\boldsymbol{H}$, In the presence of estrogen, CTB-labeled neurons $(\boldsymbol{G})$ in both peripherin-positive (arrow) and peripherin-negative (arrowhead) groups were frequently pSmad1 negative. $I$, In CTB-labeled neurons, pSmad1-immunoreactive nuclei occurred more frequently in peripherin-positive compared with peripherin-negative neurons $(p=0.004$ by 2 -way ANOVA). Both populations responded to estrogen with a reduction in the percentage of pSmad1-expressing nuclei $\left({ }^{* *} p<0.001,{ }^{* * *} p=0.034\right.$ by Student-Newman-Kuels tests). However, the decline was much stronger in the peripherin-positive population ( $p=0.007)$. All images from the L6 and S1 DRG. Scale bars, $50 \mu \mathrm{m}$. 
A

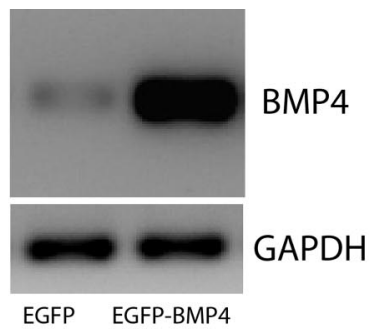

mRNA RT-PCR
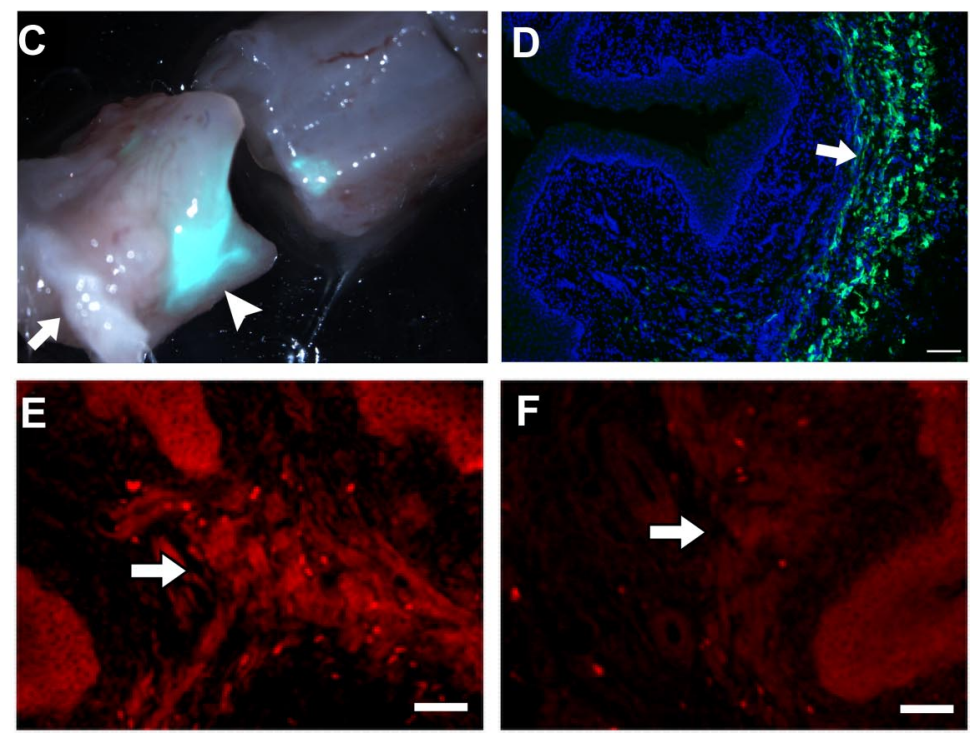

Figure 7. Lentiviral injection regulates BMP4 expression in vaginal smooth muscle. $\boldsymbol{A}, \mathrm{HEK} 293 \mathrm{~T}$ cells overexpress BMP4 as assessed by RT-PCR $48 \mathrm{~h}$ after transduction with viral particles containing vectors for EGFP-BMP4 expression compared with those with only EGFP expressing control. GAPDH was used as a housekeeping control gene. $\boldsymbol{B}$, Immunoblot showing abundant amounts of secreted BMP4 protein in conditioned media of HEK293T cells transduced with EGFP-BMP4 compared with EGFP alone. C, Bright-field and epifluorescence overlay of the whole vagina (cut transversely) shows intense EFGP fluorescence at the injection site (arrowhead) at $7 \mathrm{~d}$. Arrow indicates the vaginal orifice. D, Overlay of DAPI staining and EGFP in a section of the specimen shown in C. Arrow indicates abundant EGFP expression in the smooth muscle layer. Scale bar, $200 \mu \mathrm{m}$. $\boldsymbol{E}$, Immunostaining for BMP4 shows robust fluorescence in vaginal smooth muscle (arrow) of an estrogen-treated OVX rat transduced with EGFP_BMP4 at $7 \mathrm{~d}$. $\boldsymbol{F}$, Estrogen-treated rats receiving control virus with EGFP alone showed very low levels of BMP4 immunostaining. Scale bars: $\boldsymbol{E}, \boldsymbol{F}, 50 \mu \mathrm{m}$.

transcription factors mediating axonal outgrowth (Zou et al., 2009). If estrogen regulates axonal outgrowth by way of BMP4 signaling, then nuclear pSmad1 localization should be reduced when vaginal sensory innervation is lower. We investigated pSmad1 expression in L6-S2 DRGs, which originate vaginal innervation. Under low-estrogen conditions in OVX rats, many pSmad1-positive nuclei were evident (Fig. 6A). At $24 \mathrm{~h}$ after estrogen injection, pSmad1-immunoreactive nuclei were much less frequent (Fig. 6B), with quantitative analysis showing an $85 \%$ reduction of pSmad1labeled nuclei (Fig. 6C). Double immunostaining showed that many pSmad1-positive nuclei were present in peripherinexpressing neurons (Fig. 6D).

To confirm that changes seen globally in pSmad 1 expression also occur in vagina-projecting neurons, we assessed pSmad1-IR in retrogradely labeled L6-S2 DRG neurons (Fig. 6E, G). In OVX rats, nearly all CTB-labeled peripherin-positive neurons displayed pSmad1-IR (Fig. 6F); approximately half of the peripherin-negative CTB-labeled neurons also contained pSmad1-IR. After estrogen administration, numbers of pSmad1, CTB-labeled, peripherinpositive neurons (Fig. $6 H$ ) were reduced by $\sim 60 \%$ (Fig. $6 I$ ); nonperipherin-immunoreactive, CTB-labeled neurons showed a smaller reduction of $\sim 20 \%$ (Fig. $6 I$ ).

\section{Local viral expression of BMP4 prevents estrogen-induced nerve depletion in vivo}

These findings are consistent with the hypothesis that vaginal innervation density is regulated in part by the suppression of BMP4 synthesis by estrogen. If so, then sustained BMP4 synthesis despite estrogen elevation should prevent this reduction in innervation. We used a lentiviral delivery system to drive BMP4 gene expression by the estrogen-independent CMV promoter. The vector also expresses EGFP reporter under the ubiquitin-C promoter. Competence of the lentiviral agent was confirmed by assessing BMP4 gene and protein expression in transduced HEK293T cells (Fig. 7A,B).

OVX rats received vaginal submucosal lentiviral injections and were concurrently implanted with vehicle- or estrogen-releasing capsules and maintained for $7 \mathrm{~d}$. To identify regions that had incorporated viral gene expression, tissue was visualized using fluorescent stereomicroscopy, and the vagina was cut transversely through the region showing the greatest EGFP fluorescence (Fig. 7C). Cryosections through this region showed EGFP expression in individual cells within the vaginal smooth muscle layer (Fig. 7D). In OVX rats injected with the BMP4 vector and receiving estrogen, smooth muscle showed elevated BMP4-IR (Fig. 7E) relative to rats receiving the EGFP vector alone (Fig. $7 F$ ) and compared with regions adjacent to the injection sites.

We next determined whether sustained BMP4 expression prevents the reduction in vaginal innervation that occurs normally with estrogen elevation. OVX rats show reduced vaginal PGP9.5-immunoreactive innervation after $7 \mathrm{~d}$ of estrogen supplementation (Ting et al., 2004). Assessment of tissues adjacent to sites injected with lentivirus carrying BMP4 or EGFP constructs was similar to that described previously. Injection of lentivirus containing the EGFP vector alone also did not affect innervation as assessed using PGP9.5-IR (Fig. $8 A, C$ ) or peripherin (Fig. $8 D$ ). Sites injected with lentivirus carrying the BMP4 construct exhibited innervation patterns similar to controls but did not show the reduced innervation density normally seen after estrogen administration (Fig. $8 B-D$ ).

We investigated whether the effects of BMP4 are selective for different populations of vaginal axons. Putative peptidergic nociceptors were identified by immunostaining for CGRP (Lawson, 1992). Axon density was similar in uninjected and EGFP-vectorinjected tissues but was increased in tissues receiving BMP4 lentivirus (Fig. 9A-C). In contrast, using TH-IR as a marker for sympathetic axons, we found no differences in innervation density among any of the sampled regions (Fig. 9D).

\section{Discussion}

BMP4 regulates development of many smooth muscle targets by promoting differentiation, organization, and maturation of 
smooth muscle cells. Typically, BMP4 from adjacent epithelium, endothelium, or fibroblasts acts in a paracrine manner to regulate smooth muscle development (Frank et al., 2005; Cai, 2009; Wang et al., 2009; Tasian et al., 2010). Our findings show that, in the adult, vaginal smooth muscle cells themselves synthesize BMP4, raising the possibility that $\mathrm{BMP} 4$ may also act in an autocrine manner. Indeed, a recent report suggests that BMP4 exerts autocrine effects by promoting $\mathrm{C} 2 \mathrm{C} 12$ cell myotube formation (Umemoto et al., 2011). Hence, BMP4 may regulate smooth muscle integrity and function beyond the developmental period.

Smooth muscle cells are generally well innervated and, accordingly, secrete proteins that potentially influence axon growth and integrity. These include neurotrophins, extracellular matrix components, growth factors, and cytokines (Weintraub et al., 1996; Knox et al., 2001; Gerthoffer and Singer, 2002; Krizsan-Agbas et al., 2003, 2008). However, members of the BMP family of proteins have not been identified previously as regulators of peripheral innervation in the adult. In early development, BMP4 is critical for peripheral neuron migration and maturation, including formation of trigeminal sensory facial maps and phenotype specification of DRG neurons (Hall et al., 2002; Guha et al., 2004; Hodge et al., 2007). This study shows that BMP4 mediates peripheral sensory axon plasticity in the adult as well. DRG neurons express BMP4 receptors, and both smooth muscle-derived and exogenous BMP4 exert similar effects in stimulating sensory (but not sympathetic) axon outgrowth. BMP4 is likely to induce outgrowth by interacting with axonal receptors proximate to sites of target synthesis, although we did not demonstrate BMP4 receptors on terminals and cannot exclude effects at other regions of the axon or soma. Other members of the TGF $\beta$ family of proteins are known to interact with growth factors such as NGF to influence sensory neuron phenotype (Ai et al., 1999; Hall et al., 2002); hence, the ultimate effects of BMP4 in vivo will clearly be determined by combinatorial influences involving other local regulatory molecules. Nonetheless, our findings that DRG axon outgrowth is enhanced when BMP4 levels are increased in defined culture conditions, as well as when they are selectively increased by viral transduction in vivo, lend strong support to the idea that BMP4 acts directly as a pro-neuritogenic factor for at least some types of peripheral neurons in the mature organism.

In developing tissues, many factors regulate BMP4 expression, including FGF3, vitamin A, and the wnt and notch signaling for BMP4 Inj vs BMP4 Adj).
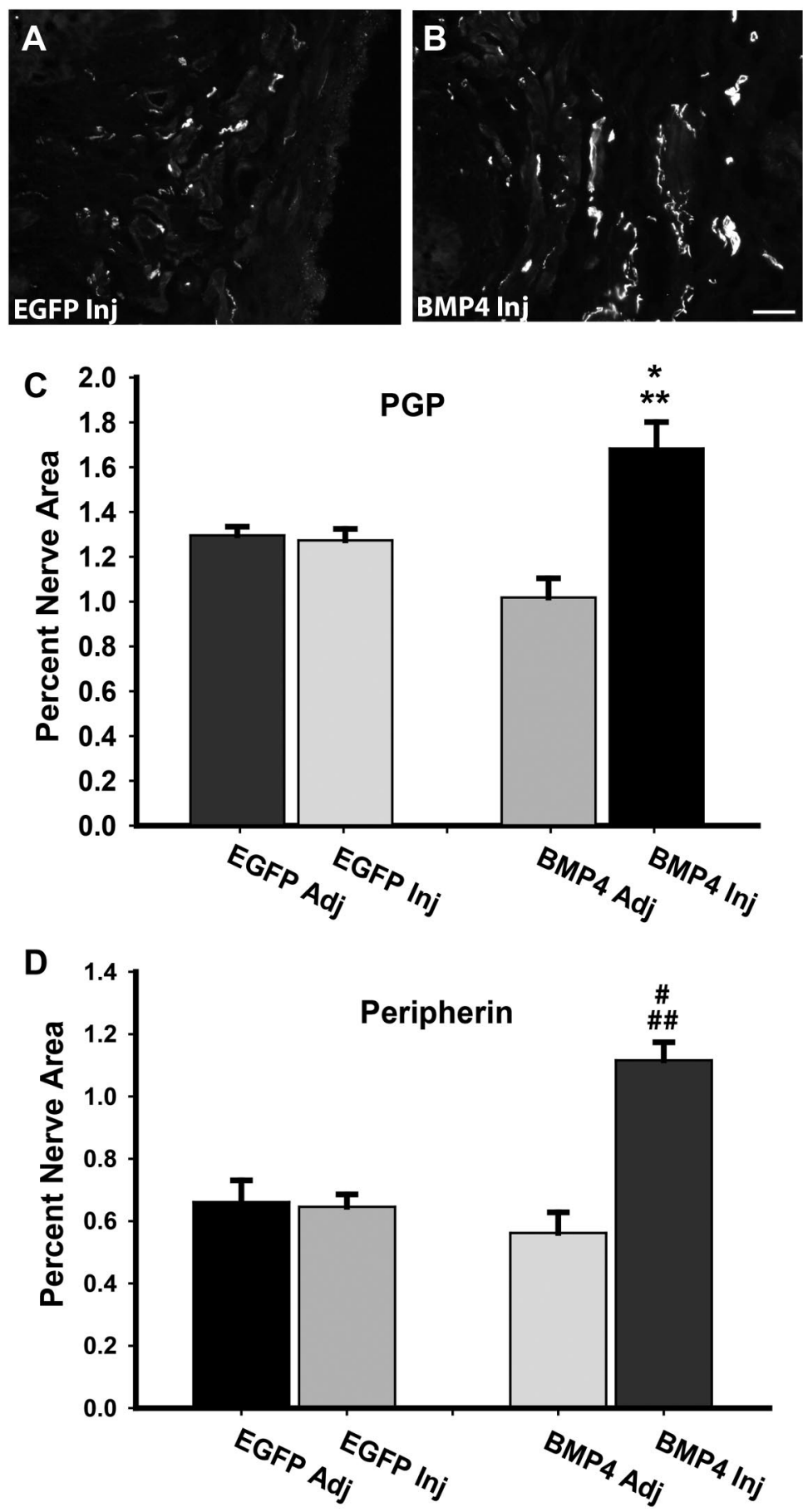

Figure 8. BMP4 overexpression preserves vaginal innervation at high estrogen. A, Immunostaining for PGP9.5 at the site of injection $7 \mathrm{~d}$ after injection of lentivirus driving expression of only EGFP (EGFP Inj) showed low innervation density typical of OVX rats receiving estrogen supplementation. $\boldsymbol{B}$, PGP-positive innervation density at sites injected with lentivirus driving BMP4 expression (BMP4 Inj) was considerably higher, characteristic of low-estrogen OVX rats. Scale bar, $50 \mu \mathrm{m}$. C, Injection of EGFP lentivirus did not alter innervation density relative to uninjected adjacent tissues (EGFP Adj), or to innervation at sites adjacent to injection with the BMP4 lentivirus (BMP4 Adj). Innervation density at sites receiving BMP4 lentivirus was significantly greater than that of other sites $\left({ }^{*} p=0.019\right.$ for BMP4 Inj vs EGFP Inj and ${ }^{* *} p=0.026$ for BMP4 Inj vs BMP4 Adj). D, Staining for peripherin confirmed that changes noted with PGP9.5 also occur within this axonal population ( ${ }^{\#} p \leq 0.001$ for BMP4 Inj vs EGFP Inj, and ${ }^{\# \#} p \leq 0.001$

pathways (Baker et al., 1999; Endo et al., 2003; Baleato et al., 2005). Much less is known about the regulation of BMP4 synthesis in mature tissues. Our findings show that estrogen is an important factor in determining BMP4 expression in adult smooth muscle. Hence, both BMP4 mRNA and protein levels are 

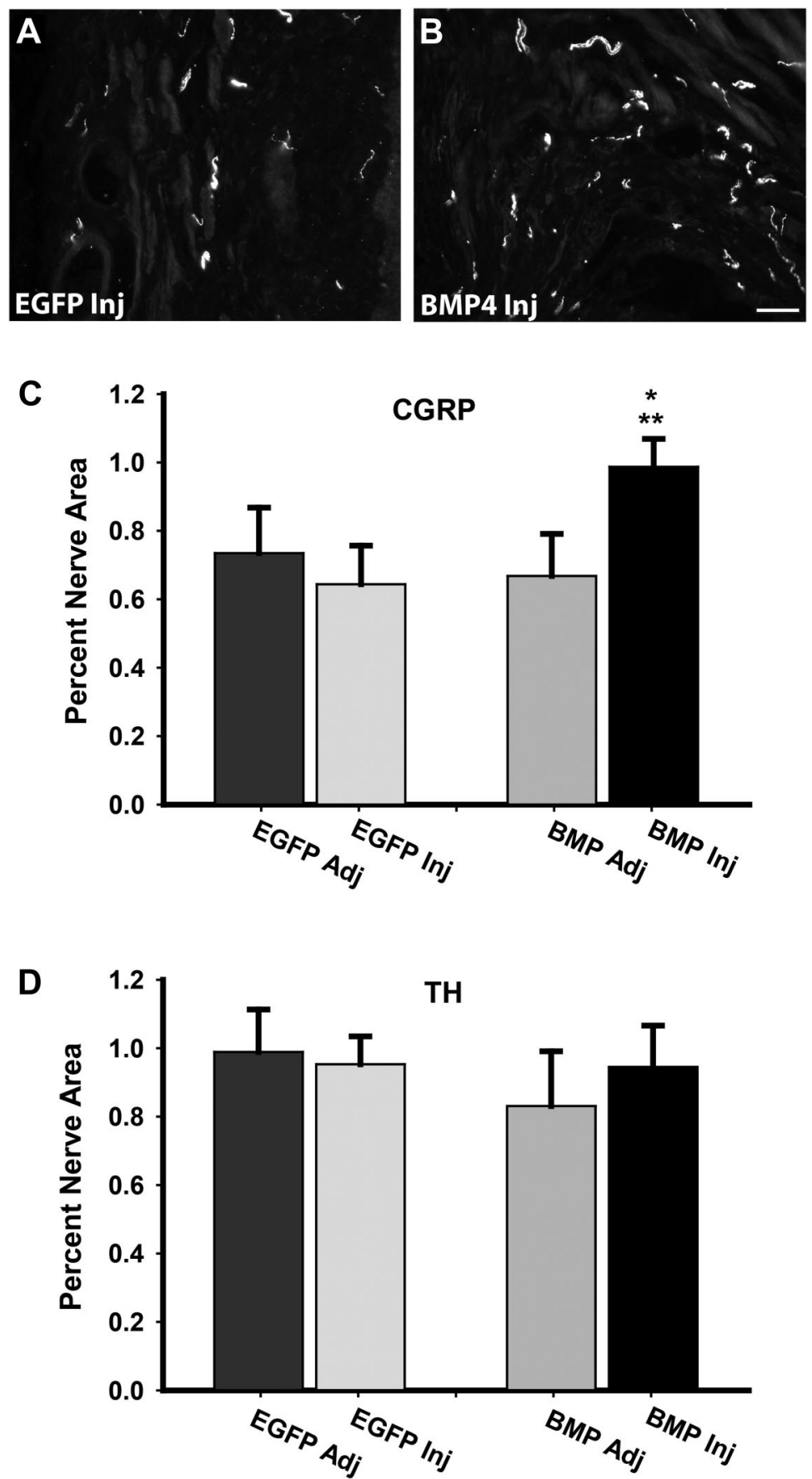

Figure 9. BMP4 overexpression selectively affects sensory innervation density. $\boldsymbol{A}$, In OVX rats receiving estrogen and injected with EGFP lentivirus (EGFP Inj), sensory axons immunoreactive for CGRP were depleted. $\boldsymbol{B}$, Sites injected with the BMP4 lentivirus (BMP4 Inj) showed higher levels of CGRP-immunoreactive innervation. Scale bar, $50 \mu \mathrm{m}$. C, Quantitative analysis confirmed that CGRP axon density in tissue receiving BMP4 lentiviral injections was greater than that of tissue adjacent to the injection site (BMP $\mathrm{Adj}_{;}{ }^{*} p=0.012$ ) and to tissue receiving EGFP lentivirus (EGFP Inj; ${ }^{* *} p=0.049$ ). $\boldsymbol{D}$, In contrast, injection with BMP4 lentivirus did not affect densities of axons expressing the sympathetic axon marker TH.

decreased when vaginal tissue is cultured in the presence of estrogen. Because these studies were conducted ex vivo, we can exclude the possibility that estrogen acts indirectly by altering other hormonal systems. Similarly, because vaginal smooth muscle cells possess estrogen receptors, this is most likely a direct effect on the smooth muscle (although we cannot exclude paracrine effects by other estrogen-responsive cells in the explant). Consistent with a direct effect of estrogen, in silico analysis reveals several putative estrogen receptor elements upstream of the BMP4 gene (data not shown). As illustrated by our findings at $24 \mathrm{~h}$ ex vivo and $7 \mathrm{~d}$ in vivo, estrogen has both short-term and sustained regulatory effects on BMP4 expression. The idea that estrogen is a negative regulator of BMP4 expression is supported by a recent report that BMP4 levels are elevated in prostate gland stromal cells of the estrogen receptor $\alpha$ knock-out mouse (Chen et al., 2009). It therefore appears that estrogen can act to suppress BMP4 synthesis in multiple mature tissues types.

A striking feature of the female reproductive tract is the extensive and relatively rapid degree to which innervation remodeling occurs in conjunction with varying reproductive states. Our findings are consistent with the hypothesis that BMP4 plays a major role in this remodeling. Dispersed DRG neuron-vaginal smooth muscle cocultures showed that the ability of estrogen to diminish axon sprouting is fully reversed by adding exogenous BMP4, supporting the idea that this cytokine is responsible for outgrowth under low-estrogen conditions. This was illustrated most vividly in in vivo lentiviral transduction studies in which smooth muscle cells containing the estrogen-independent CMV-promoterdriven BMP4 transcript showed high levels of sensory innervation, whereas regions immediately adjacent that had only native, estrogen-dependent BMP4 expression showed markedly reduced innervation. Therefore, diminished BMP4 expression accounts, at least in part, for reduced vaginal innervation density when estrogen levels rise.

Several lines of evidence show that BMP-Smad signaling plays a crucial role in nerve regeneration after injury. Analysis of the DRG neuron transcriptome after distal axon injury showed that Smad1 is strongly upregulated during regeneration and that this transcription factor is obligatory, because siRNA knockdown abrogated regenerative outgrowth (Zou et al., 2009). The importance of BMP induction of Smad1 in axon regeneration has been shown recently in studies of DRG neurons after spinal cord injury. Central DRG axons, which normally show minimal regenerative capacity, displayed robust outgrowth when BMP4 was overexpressed in neurons by viral transduction (Parikh et al., 2011). In contrast, blocking BMP signaling by administering noggin or ablating the BMP coreceptor RMGb inhibited DRG neuronal outgrowth after axotomy (Ma et al., 2011). Therefore, BMPs acting through the Smad1 pathway are among a number of cytokines (Dubový, 2011) implicated in the initiation of axon regeneration after injury.

We show here that BMP4/Smad1 signaling is also critical in determining target innervation under physiological conditions. In 
lumbar DRGs giving rise to vaginal innervation, low estrogen levels after ovariectomy were accompanied by high vaginal innervation density (presumably a result of axon sprouting), and levels of nuclear pSmad1 were high in peripherin-expressing neurons, including those projecting to the vagina. Although possible contributions of noncanonical signaling mechanisms cannot be ruled out, these findings support the hypothesis that smooth musclederived BMP4 acts on DRG peripherin-positive neurons to induce Smad1 phosphorylation and nuclear translocation as a prelude to terminal sensory axon outgrowth in the estrogendeprived vagina.

Alterations in estrogen status are associated with changes in vaginal autonomic as well as sensory innervation in both rats and humans (Ting et al., 2004; Griebling et al., 2012). Although lentiviral BMP4 overexpression mimicked the effect of ovariectomy on CGRP-immunoreactive sensory axons, TH-expressing sympathetic axons were unaffected. This implies that, although both sensory and autonomic neuronal progenitors are responsive to BMP4 (Guha et al., 2004; Liu et al., 2005), BMP4 influences only sensory innervation density in the mature organism. It is unclear why mature sympathetic neurons are not responsive, but it seems likely that other estrogen-regulated factors are involved in achieving the full repertoire of vaginal axon remodeling. Estrogen is known to influence the expression of trophic proteins (Bjorling et al., 2002), as well as factors that are repulsive to sympathetic axons (Krizsan-Agbas et al., 2003, 2008; Richeri et al., 2011). Hence, although our findings show that BMP4 signaling is necessary and sufficient to achieve high levels of sensory innervation, it is clear that estrogen-mediated regulation of reproductive tract innervation involves complex interactions at the level of the target and neuron.

Abnormal sensory innervation is a hallmark feature of some female pain syndromes. Vulvodynia, characterized by abnormal sensitivity of the genital tissues, affects $\sim 16 \%$ of the adult female population (Harlow and Stewart, 2003), and the "provoked" form of this disorder is associated with marked hyperinnervation of the vaginal vestibule by CGRP-immunoreactive axons (BohmStarke et al., 1999; Tympanidis et al., 2003) and impaired estrogen receptor signaling (Eva et al., 2003); excising the hyperinnervated region frequently alleviates the pain (Goetsch, 1996). "Spontaneous" vulvodynia selectively affects perimenopausal women, in which estrogen levels are low and vaginal hyperinnervation also occurs (Griebling et al., 2012). Although the present study does not directly demonstrate that BMP4 elevation leads to hypersensitivity, several lines of evidence support this concept: (1) Smad signaling pathways activated by BMP4 and related ligands are implicated in regulating DRG neuron excitability and pain sensitivity (Jeub et al., 2011); (2) our findings show that BMP4 selectively promotes sprouting of axons with a peripherin/CGRP-positive phenotype corresponding to smalldiameter nociceptors (Bove and Light, 1995; Goldstein et al., 1996), and axons with this phenotype appear to be obligatory for detecting some types of noxious stimuli (McCoy et al., 2012); (3) the proliferation of these axons in OVX comports well with the previously documented hypersensitivity to vaginal distension that occurs under this low-estrogen condition (Bradshaw and Berkley, 2002; Ting et al., 2004); and (4) proliferation of peripheral axons of comparable phenotype is now documented as a common feature of many painful conditions (Di Sebastiano et al., 1995; Brown et al., 1997; Schubert et al., 2005; Tague et al., 2011). Although additional research is required to fully define the interrelationships among innervation, estrogen, and pain sensitivity, BMP4 clearly represents a potent estrogen-regulated determinant of peripheral sensory innervation.

\section{References}

Abir R, Ben-Haroush A, Melamed N, Felz C, Krissi H, Fisch B (2008) Expression of bone morphogenetic proteins 4 and 7 and their receptors IA, IB, and II in human ovaries from fetuses and adults. Fertil Steril 89:14301440. CrossRef Medline

Ai X, Cappuzzello J, Hall AK (1999) Activin and bone morphogenetic proteins induce calcitonin gene-related peptide in embryonic sensory neurons in vitro. Mol Cell Neurosci 14:506-518. CrossRef Medline

Baker JC, Beddington RS, Harland RM (1999) Wnt signaling in Xenopus embryos inhibits bmp4 expression and activates neural development. Genes Dev 13:3149-3159. CrossRef Medline

Baleato RM, Aitken RJ, Roman SD (2005) Vitamin A regulation of BMP4 expression in the male germ line. Dev Biol 286:78-90. CrossRef Medline

Berkley KJ, Robbins A, Sato Y (1993) Functional differences between afferent fibers in the hypogastric and pelvic nerves innervating female reproductive organs in the rat. J Neurophysiol 69:533-544. Medline

Bjorling DE, Beckman M, Clayton MK, Wang ZY (2002) Modulation of nerve growth factor in peripheral organs by estrogen and progesterone. Neuroscience 110:155-167. CrossRef Medline

Bohm-Starke N, Hilliges M, Falconer C, Rylander E (1999) Neurochemical characterization of the vestibular nerves in women with vulvar vestibulitis syndrome. Gynecol Obstet Invest 48:270-275. CrossRef Medline

Bove GM, Light AR (1995) Calcitonin gene-related peptide and peripherin immunoreactivity in nerve sheaths. Somatosens Mot Res 12:49-57. CrossRef Medline

Bradshaw HB, Berkley KJ (2002) Estrogen replacement reverses ovariectomyinduced vaginal hyperalgesia in the rat. Maturitas 41:157-165. CrossRef Medline

Brauer MM (2008) Cellular and molecular mechanisms underlying plasticity in uterine sympathetic nerves. Auton Neurosci 140:1-16. CrossRef Medline

Brown MF, Hukkanen MV, McCarthy ID, Redfern DR, Batten JJ, Crock HV, Hughes SP, Polak JM (1997) Sensory and sympathetic innervation of the vertebral endplate in patients with degenerative disc disease. J Bone Joint Surg Br 79:147-153. CrossRef Medline

Cai Y (2009) Revisiting old vaginal topics: conversion of the Mullerian vagina and origin of the "sinus" vagina. Int J Dev Biol 53:925-934. CrossRef Medline

Cao JM, Fishbein MC, Han JB, Lai WW, Lai AC, Wu TJ, Czer L, Wolf PL, Denton TA, Shintaku IP, Chen PS, Chen LS (2000) Relationship between regional cardiac hyperinnervation and ventricular arrhythmia. Circulation 101:1960-1969. CrossRef Medline

Chakrabarty A, Blacklock A, Svojanovsky S, Smith PG (2008) Estrogen elicits dorsal root ganglion axon sprouting via a renin-angiotensin system. Endocrinology 149:3452-3460. CrossRef Medline

Chakrabarty A, McCarson KE, Smith PG (2011) Hypersensitivity and hyperinnervation of the rat hind paw following carrageenan-induced inflammation. Neurosci Lett 495:67-71. CrossRef Medline

Chen M, Hsu I, Wolfe A, Radovick S, Huang K, Yu S, Chang C, Messing EM, Yeh S (2009) Defects of prostate development and reproductive system in the estrogen receptor-alpha null male mice. Endocrinology 150:251259. CrossRef Medline

Clarke GL, Bhattacherjee A, Tague SE, Hasan W, Smith PG (2010) $\beta$-Adrenoceptor blockers increase cardiac sympathetic innervation by inhibiting autoreceptor suppression of axon growth. J Neurosci 30:1244612454. CrossRef Medline

Di Sebastiano P, Fink T, Weihe E, Friess H, Beger HG, Büchler M (1995) Changes of protein gene product 9.5 (PGP 9.5) immunoreactive nerves in inflamed appendix. Dig Dis Sci 40:366-372. CrossRef Medline

Dubový P (2011) Wallerian degeneration and peripheral nerve conditions for both axonal regeneration and neuropathic pain induction. Ann Anat 193:267-275. CrossRef Medline

Endo Y, Osumi N, Wakamatsu Y (2003) Deltex/Dtx mediates NOTCH signaling in regulation of Bmp4 expression in cranial neural crest formation during avian development. Dev Growth Differ 45:241-248. CrossRef Medline

Eva LJ, MacLean AB, Reid WM, Rolfe KJ, Perrett CW (2003) Estrogen receptor expression in vulvar vestibulitis syndrome. Am J Obstet Gynecol 189:458-461. CrossRef Medline

Ferri GL, Sabani A, Abelli L, Polak JM, Dahl D, Portier MM (1990) Neuronal intermediate filaments in rat dorsal root ganglia: differential distribu- 
tion of peripherin and neurofilament protein immunoreactivity and effect of capsaicin. Brain Res 515:331-335. CrossRef Medline

Fornaro M, Lee JM, Raimondo S, Nicolino S, Geuna S, GiacobiniRobecchi M (2008) Neuronal intermediate filament expression in rat dorsal root ganglia sensory neurons: an in vivo and in vitro study. Neuroscience 153:1153-1163. CrossRef Medline

Forsberg JG (1995) A morphologist's approach to the vagina-age-related changes and estrogen sensitivity. Maturitas [Suppl] 22:S7-S15. CrossRef Medline

Frank DB, Abtahi A, Yamaguchi DJ, Manning S, Shyr Y, Pozzi A, Baldwin HS, Johnson JE, de Caestecker MP (2005) Bone morphogenetic protein 4 promotes pulmonary vascular remodeling in hypoxic pulmonary hypertension. Circ Res 97:496-504. CrossRef Medline

Gerthoffer WT, Singer CA (2002) Secretory functions of smooth muscle: cytokines and growth factors. Mol Interv 2:447-456. CrossRef Medline

Giraldi A, Alm P, Werkström V, Myllymäki L, Wagner G, Andersson KE (2002) Morphological and functional characterization of a rat vaginal smooth muscle sphincter. Int J Impot Res 14:271-282. CrossRef Medline

Goetsch MF (1996) Simplified surgical revision of the vulvar vestibule for vulvar vestibulitis. Am J Obstet Gynecol 174:1701-1705, discussion 1705-1707. CrossRef Medline

Goldstein ME, House SB, Gainer H (1991) NF-L and peripherin immunoreactivities define distinct classes of rat sensory ganglion cells. J Neurosci Res 30:92-104. CrossRef Medline

Goldstein ME, Grant P, House SB, Henken DB, Gainer H (1996) Developmental regulation of two distinct neuronal phenotypes in rat dorsal root ganglia. Neuroscience 71:243-258. CrossRef Medline

Griebling TL, Liao Z, Smith PG (2012) Systemic and topical hormone therapies reduce vaginal innervation density in post-menopausal women. Menopause 19:630-635. CrossRef Medline

Guha U, Gomes WA, Samanta J, Gupta M, Rice FL, Kessler JA (2004) Target-derived BMP signaling limits sensory neuron number and the extent of peripheral innervation in vivo. Development 131:1175-1186. CrossRef Medline

Hall AK, Burke RM, Anand M, Dinsio KJ (2002) Activin and bone morphogenetic proteins are present in perinatal sensory neuron target tissues that induce neuropeptides. J Neurobiol 52:52-60. CrossRef Medline

Harlow BL, Stewart EG (2003) A population-based assessment of chronic unexplained vulvar pain: have we underestimated the prevalence of vulvodynia? J Am Med Womens Assoc 58:82-88. Medline

Hasan W, Jama A, Donohue T, Wernli G, Onyszchuk G, Al-Hafez B, Bilgen M, Smith PG (2006) Sympathetic hyperinnervation and inflammatory cell NGF synthesis following myocardial infarction in rats. Brain Res 1124:142-154. CrossRef Medline

Hodge LK, Klassen MP, Han BX, Yiu G, Hurrell J, Howell A, Rousseau G, Lemaigre F, Tessier-Lavigne M, Wang F (2007) Retrograde BMP signaling regulates trigeminal sensory neuron identities and the formation of precise face maps. Neuron 55:572-586. CrossRef Medline

Jeub M, Emrich M, Pradier B, Taha O, Gailus-Durner V, Fuchs H, de Angelis MH, Huylebroeck D, Zimmer A, Beck H, Racz I (2011) The transcription factor Smad-interacting protein 1 controls pain sensitivity via modulation of DRG neuron excitability. Pain 152:2384-2398. CrossRef Medline

Knox AJ, Corbett L, Stocks J, Holland E, Zhu YM, Pang L (2001) Human airway smooth muscle cells secrete vascular endothelial growth factor: up-regulation by bradykinin via a protein kinase $\mathrm{C}$ and prostanoiddependent mechanism. FASEB J 15:2480-2488. CrossRef Medline

Krizsan-Agbas D, Pedchenko T, Hasan W, Smith PG (2003) Oestrogen regulates sympathetic neurite outgrowth by modulating brain derived neurotrophic factor synthesis and release by the rodent uterus. Eur J Neurosci 18:2760-2768. CrossRef Medline

Krizsan-Agbas D, Pedchenko T, Smith PG (2008) Neurotrimin is an estrogen-regulated determinant of peripheral sympathetic innervation. J Neurosci Res 86:3086-3095. CrossRef Medline

Latini C, Frontini A, Morroni M, Marzioni D, Castellucci M, Smith PG (2008) Remodeling of uterine innervation. Cell Tissue Res 334:1-6. CrossRef Medline

Lauria G, Lombardi R, Borgna M, Penza P, Bianchi R, Savino C, Canta A, Nicolini G, Marmiroli P, Cavaletti G (2005) Intraepidermal nerve fiber density in rat foot pad: neuropathologic-neurophysiologic correlation. J Peripher Nerv Syst 10:202-208. CrossRef Medline

Lawson S (1992) Morphological and biochemical cell types of sensory neu- rons. In: Sensory neurons: diversity, development, and plasticity (Scott SA, ed), pp 27-59. New York: Oxford UP.

Liao Z, Smith PG (2011) Adaptive plasticity of vaginal innervation in term pregnant rats. Reprod Sci 18:1237-1245. CrossRef Medline

Liu H, Margiotta JF, Howard MJ (2005) BMP4 supports noradrenergic differentiation by a PKA-dependent mechanism. Dev Biol 286:521-536. CrossRef Medline

Ma CH, Brenner GJ, Omura T, Samad OA, Costigan M, Inquimbert P, Niederkofler V, Salie R, Sun CC, Lin HY, Arber S, Coppola G, Woolf CJ, Samad TA (2011) The BMP coreceptor RGMb promotes while the endogenous BMP antagonist noggin reduces neurite outgrowth and peripheral nerve regeneration by modulating BMP signaling. J Neurosci 31: 18391-18400. CrossRef Medline

MacLean AB, Nicol LA, Hodgins MB (1990) Immunohistochemical localization of estrogen receptors in the vulva and vagina. J Reprod Med 35: 1015-1016. Medline

McCoy ES, Taylor-Blake B, Zylka MJ (2012) CGRPalpha-expressing sensory neurons respond to stimuli that evoke sensations of pain and itch. PLoS One 7:e36355. CrossRef Medline

McMahon JA, Takada S, Zimmerman LB, Fan CM, Harland RM, McMahon AP (1998) Noggin-mediated antagonism of BMP signaling is required for growth and patterning of the neural tube and somite. Genes Dev 12:1438-1452. CrossRef Medline

Miyazono K, Kamiya Y, Morikawa M (2010) Bone morphogenetic protein receptors and signal transduction. J Biochem 147:35-51. CrossRef Medline

Mowa CN, Iwanaga T (2000) Differential distribution of oestrogen receptor-alpha and -beta mRNAs in the female reproductive organ of rats as revealed by in situ hybridization. J Endocrinol 165:59-66. CrossRef Medline

Parikh P, Hao Y, Hosseinkhani M, Patil SB, Huntley GW, Tessier-Lavigne M, Zou H (2011) Regeneration of axons in injured spinal cord by activation of bone morphogenetic protein/Smad1 signaling pathway in adult neurons. Proc Natl Acad Sci U S A 108:E99-E107. CrossRef Medline

Richeri A, Chalar C, Martinez G, Greif G, Bianchimano P, Brauer MM (2011) Estrogen up-regulation of semaphorin $3 \mathrm{~F}$ correlates with sympathetic denervation of the rat uterus. Autonomic neuroscience: basic and clinical 164:43-50. CrossRef

Schubert TE, Weidler C, Lerch K, Hofstädter F, Straub RH (2005) Achilles tendinosis is associated with sprouting of substance $\mathrm{P}$ positive nerve fibres. Ann Rheum Dis 64:1083-1086. CrossRef Medline

Sela-Donenfeld D, Kalcheim C (1999) Regulation of the onset of neural crest migration by coordinated activity of BMP4 and Noggin in the dorsal neural tube. Development 126:4749-4762. Medline

Ström JO, Theodorsson E, Theodorsson A (2008) Order of magnitude differences between methods for maintaining physiological 17betaoestradiol concentrations in ovariectomized rats. Scand J Clin Lab Invest 68:814-822. CrossRef Medline

Tague SE, Smith PG (2011) Vitamin D receptor and enzyme expression in dorsal root ganglia of adult female rats: modulation by ovarian hormones. J Chem Neuroanat 41:1-12. CrossRef Medline

Tague SE, Clarke GL, Winter MK, McCarson KE, Wright DE, Smith PG (2011) Vitamin D deficiency promotes skeletal muscle hypersensitivity and sensory hyperinnervation. J Neurosci 31:13728-13738. CrossRef Medline

Tasian G, Cunha G, Baskin L (2010) Smooth muscle differentiation and patterning in the urinary bladder. Differentiation 80:106-117. CrossRef Medline

Ting AY, Blacklock AD, Smith PG (2004) Estrogen regulates vaginal sensory and autonomic nerve density in the rat. Biol Reprod 71:1397-1404. CrossRef Medline

Tympanidis P, Terenghi G, Dowd P (2003) Increased innervation of the vulval vestibule in patients with vulvodynia. Br J Dermatol 148:1021-1027. CrossRef Medline

Umemoto T, Furutani Y, Murakami M, Matsui T, Funaba M (2011) Endogenous Bmp4 in myoblasts is required for myotube formation in $\mathrm{C} 2 \mathrm{C} 12$ cells. Biochim Biophys Acta 1810:1127-1135. CrossRef Medline

Wang GJ, Brenner-Anantharam A, Vaughan ED, Herzlinger D (2009) Antagonism of BMP4 signaling disrupts smooth muscle investment of the ureter and ureteropelvic junction. J Urol 181:401-407. CrossRef Medline Weintraub AS, Giachelli CM, Krauss RS, Almeida M, Taubman MB (1996) 
Autocrine secretion of osteopontin by vascular smooth muscle cells regulates their adhesion to collagen gels. Am J Pathol 149:259-272. Medline

Zhang D, Mehler MF, Song Q, Kessler JA (1998) Development of bone morphogenetic protein receptors in the nervous system and possible roles in regulating trkC expression. J Neurosci 18:3314-3326. Medline

Zou H, Ho C, Wong K, Tessier-Lavigne M (2009) Axotomy-induced Smad1 activation promotes axonal growth in adult sensory neurons. J Neurosci 29:7116-7123. CrossRef Medline

Zoubina EV, Mize AL, Alper RH, Smith PG (2001) Acute and chronic estrogen supplementation decreases uterine sympathetic innervation in ovariectomized adult virgin rats. Histol Histopathol 16:989-996. Medline 